(2) Open Access Full Text Article

\title{
Improvement of interferon-beta related skin reactions after diluent halving: first experience of five patients
}

This article was published in the following Dove Press journal:

Patient Preference and Adherence

7 August 2012

Number of times this article has been viewed

\section{Chiara Zecca' \\ Nikhil Yawalkar ${ }^{2}$ \\ Claudio Gobbi'}

'Neurocenter of Southern Switzerland, Lugano, ${ }^{2}$ Department of Dermatology, Bern University Hospital, Bern, Switzerland
Correspondence: Claudio Gobbi Neurocenter of Southern Switzerland, Ospedale Regionale di Lugano, Via Tesserete 46, 6903 Lugano, Switzerland $\mathrm{Tel}+4|9| 8|| 6921$

$\mathrm{Fax}+41918116915$

Email claudio.gobbi@eoc.ch
Background: The spectrum of side effects related to interferon beta- $1 \mathrm{~b}$ (INF-1b) treatment may compromise long-term adherence.

Methods: Five INF-1b-treated multiple sclerosis patients with poor skin tolerability and clinical stability were instructed to dissolve the established $(250 \mu \mathrm{g})$ INF-1b dose in half $(0.5 \mathrm{~mL})$ the standard diluent ( $1.0 \mathrm{~mL}, 0.54 \%$ sodium chloride solution), and were followed for 9 months.

Results: Halving the volume of the treatment diluent was associated with significant improvement of skin side effects profile in all patients. The improvement was sustained for 9 months.

Conclusion: Halving the volume of the INF-1b diluent could represent a different strategy to optimize skin tolerability and adherence in some multiple sclerosis patients.

Keywords: multiple sclerosis, interferon, treatment tolerability, side effects, skin reactions

\section{Introduction}

Immunomodulation with injectable interferon-beta (INF) and glatiramer acetate has been validated in pivotal phase III trials,,${ }^{1-4}$ and represents the first-line treatment in multiple sclerosis (MS). However, the side effect spectrum of these drugs has a possible negative impact on patient's quality of life. In turn, this may lead patients to reduce treatment adherence, with obvious negative influence on clinical outcome. ${ }^{5}$ Physicians might thus be forced to switch effective MS treatments to other therapies due to relevant local or systemic side effects. New strategies to minimize and manage the known INF-related side effects are thus of major interest in order to guarantee, besides optimal efficacy, the best treatment adherence and acceptance.

In this report, five MS patients - who have clinical and radiological disease stability but suffer severe skin reactions related to INF-1b injections - experienced a marked improvement in skin tolerability after halving the diluent volume while maintaining the same INF-1b dose.

\section{Representative case}

An otherwise healthy 33-year-old female presented with subacute gait ataxia and urinary hesitancy in March 2007. Neurological examination showed an impairment of leg proprioception and mild pyramidal signs. Following appropriate diagnostic work-up, a clinically isolated syndrome was diagnosed. Treatment with steroids led to partial recovery (Expanded Disability Status Score from 3.5 to 2.0). Four months later, the patient presented with a right optic neuritis, which recovered after a high dose steroid course. Treatment with INF-1b $250 \mu \mathrm{g}$ subcutaneously every other day was started. 
During the following 4 years she had no further attacks, disability progression, or new lesions at follow-up magnetic resonance imaging. Unfortunately, in April 2011 the patient presented with marked erythema and hardened skin changes at injection sites on her abdomen and legs. She was absolutely reluctant to change treatment due to fear of inefficacy and possible severe complications of second-line therapies; she was thus instructed to reconstitute the lyophilized INF-1b to half of the volume of the supplied diluent $(0.54 \%$ sodium chloride solution), according to anecdotal evidence from patients' and nurses' clinical practice. After this change, the patient much better tolerated the injections with only mild local erythema. During the following 9 months, she remained clinically stable with good treatment compliance. No further severe local or systemic side effects occurred.

Based on this experience, the same treatment regimen was given to four further patients with severe skin reactions and clinical stability under INF-1b treatment. They gave their consent for this treatment change. A nurse specialized in MS injectable treatments instructed patients at home and followed them as necessary. Patients were clinically evaluated every 3 months with standard laboratory assessment for INF-1b treatment; moreover, they had a monthly phone interview for safety monitoring. Severity of skin and systemic side effects before and after treatment change were assessed by visual analog scales and objective medical evaluation (Tables 1 and 2).

\section{Discussion}

Five patients with severe injection site reactions to INF-1b clearly improved after reduction of the volume of the injected INF-1b solution. This was achieved by halving the diluent volume of each injection, thus maintaining the standard INF-1b dose. Skin amelioration generally occurred after $\geq 3$ months following treatment change and involved tenderness, redness, and local injury and was associated with an improvement of global patient's satisfaction of treatment as assessed by visual analog scales. Moreover, halving the solution volume was neither associated with a worsening of the systemic side effect profile or with a reduction of clinical efficacy during the follow-up.

Based on clinical trials ${ }^{6}$ and patients' experience, local skin reactions and systemic side effects generally increase with INF titration, which represents a standard of care to optimize INF tolerability; nevertheless, higher INF doses are usually associated with more frequent and intense side effects. ${ }^{1,4,7,8}$ Until now, no studies have clarified whether this effect is due to the progressively increased injected volume, INF dose, or both.

It was speculated that the injected volume could play a role in INF-1b-associated skin reactions. Five patients were accordingly treated with the standard INF-1b dose in half the standard diluent volume. Intriguingly, this procedure led to a significant improvement of the local inflammatory reactions in all patients after approximately 3 months. The clear temporal association between diluent halving and the improvement of skin symptoms points to a direct role of the injected volume in INF-1b-associated skin reactions. Pathogenetic mechanisms underlying INF-associated injection site reactions are still poorly understood. Injection technique, needle size, depth of injection, and mechanical and inflammatory/immunological changes triggered by the injection process itself or by the injected drug or diluent could represent contributing factors. It has been shown that subcutaneous adipose tissue can release multiple proinflammatory cytokines and chemokines such as interleukin-1 beta, interleukin-6, tumor necrosis factor-alpha, and CXCL8 (interleukin-8) even after minimal trauma. ${ }^{9}$ Therefore, reduction of the injected volume may lead to less mechanical trauma and reduced activation of the surrounding adipocytes, nerve cells, and immune cells, subsequently leading to a decreased amount of inflammation. It is improbable that diluent components $(0.54 \%$ sodium chloride solution) play a major role in the

Table I Clinical and demographic characteristics of patients at baseline and at 9 months follow-up

\begin{tabular}{|c|c|c|c|c|c|c|c|c|c|}
\hline \multirow[t]{2}{*}{ Patient } & \multicolumn{7}{|c|}{ Baseline clinical and demographics } & \multicolumn{2}{|c|}{$\begin{array}{l}\text { Clinical course at } \\
9 \text { months }\end{array}$} \\
\hline & Sex & Age & $\begin{array}{l}\text { Disease } \\
\text { duration }\end{array}$ & $\begin{array}{l}\text { INF-Ib } \\
\text { duration } \\
\text { (years) }\end{array}$ & $\begin{array}{l}\text { EDSS } 2 \text { years prior } \\
\text { to treatment changel } \\
\text { at baseline }\end{array}$ & $\begin{array}{l}\text { ARR } \\
\text { (last } 2 \text { years) }\end{array}$ & $\begin{array}{l}\text { Previous treatments } \\
\text { (I year prior } \\
\text { to INF-I b) }\end{array}$ & $\begin{array}{l}\text { Number } \\
\text { of relapses }\end{array}$ & EDSS \\
\hline I & $\mathrm{F}$ & 37 & 4 & 4 & $2.0 / 2.0$ & 0 & - & 0 & 2.0 \\
\hline 2 & $\mathrm{~F}$ & 63 & 33 & 11 & $2.0 / 2.0$ & 0 & - & 0 & 2.0 \\
\hline 3 & $\mathrm{~F}$ & 44 & 4 & 4 & $2.0 / 2.0$ & 0 & - & 0 & 2.0 \\
\hline 4 & $\mathrm{~F}$ & 60 & 7 & 7 & $2.0 / 2.0$ & 0 & - & 0 & 2.0 \\
\hline 5 & $\mathrm{~F}$ & 51 & 2 & 2 & $1.0 / 1.0$ & 0 & - & 0 & 1.0 \\
\hline
\end{tabular}

Abbreviations: ARR, annual relapse rate; EDSS, Expanded Disability Status Score; F, female; INF, interferon beta-Ib. 
Table 2 Evaluation of treatment-related side effects and treatment satisfaction

\begin{tabular}{|c|c|c|c|c|c|c|c|c|c|c|c|c|c|c|c|}
\hline \multirow[t]{3}{*}{$\mathbf{P t}$} & \multicolumn{13}{|c|}{ Patients' evaluation of local and systemic side effects } & \multicolumn{2}{|c|}{$\begin{array}{l}\text { Medical evaluation } \\
\text { of skin lesions }\end{array}$} \\
\hline & \multicolumn{2}{|c|}{ Redness } & \multicolumn{2}{|c|}{ Tenderness } & \multicolumn{2}{|c|}{ Necrosis } & \multicolumn{2}{|c|}{$\begin{array}{l}\text { Pain at } \\
\text { injection site }\end{array}$} & \multicolumn{2}{|c|}{$\begin{array}{l}\text { Flu-like } \\
\text { symptoms }\end{array}$} & \multicolumn{2}{|c|}{ Headache } & \multirow{2}{*}{$\begin{array}{l}\text { Treatment } \\
\text { satisfaction } \\
\text { T9 }\end{array}$} & \multirow[t]{2}{*}{$\begin{array}{l}\text { Tenderness } \\
\text { T9 }\end{array}$} & \multirow[t]{2}{*}{$\begin{array}{l}\text { Redness } \\
\text { T9 }\end{array}$} \\
\hline & TO & T9 & T0 & T9 & TO & T9 & $\overline{\text { TO }}$ & T9 & TO & T9 & TO & T9 & & & \\
\hline 1 & 9 & 3 & 10 & 6 & 0 & 0 & 8 & 5 & 7 & 4 & 8 & 8 & 6 & $\begin{array}{l}\text { Marked } \\
\text { improvement }\end{array}$ & $\begin{array}{l}\text { Marked } \\
\text { improvement }\end{array}$ \\
\hline 2 & 10 & 5 & 8 & 4 & 2 & 0 & 8 & 4 & 2 & 2 & 0 & 0 & 5 & $\begin{array}{l}\text { Slight } \\
\text { improvement }\end{array}$ & $\begin{array}{l}\text { Moderate } \\
\text { improvement }\end{array}$ \\
\hline 3 & 10 & 8 & 10 & 8 & 0 & 0 & 10 & 10 & 0 & 0 & 8 & 8 & 5 & $\begin{array}{l}\text { Slight } \\
\text { improvement }\end{array}$ & $\begin{array}{l}\text { Slight } \\
\text { improvement }\end{array}$ \\
\hline 4 & 6 & 3 & 3 & I & 0 & 0 & 4 & 2 & 0 & 0 & I & I & 7 & $\begin{array}{l}\text { Moderate } \\
\text { improvement }\end{array}$ & $\begin{array}{l}\text { Moderate } \\
\text { improvement }\end{array}$ \\
\hline 5 & 5 & 2 & 8 & 3 & 0 & 0 & 9 & 0 & 0 & 0 & 3 & 3 & 9 & $\begin{array}{l}\text { Moderate } \\
\text { improvement }\end{array}$ & $\begin{array}{l}\text { Moderate } \\
\text { improvement }\end{array}$ \\
\hline
\end{tabular}

Note: Patients' evaluations refer to scoring by visual analog scales ( $1-10$ scoring).

Abbreviations: Pt, patient; T0, before treatment change; T9, 9 months after treatment change.

local inflammatory processes as they are standard concentrated constituents of the extracellular spaces.

\section{Conclusion}

Halving the volume of INF-1b diluent could represent an easy and feasible alternative strategy to minimizing poor skin tolerability while continuing a previously efficacious and safe treatment. However, definitive conclusions cannot be drawn from the current case series due to the small number of patients and the descriptive context. Thus, potential employment of this formulation is subject to the positive outcome of an appropriate controlled trial.

\section{Acknowledgment}

The authors thank Dr Liliane Petrini, Neurocenter of Southern Switzerland for help with revision of the manuscript.

\section{Disclosure}

Chiara Zecca and Claudio Gobbi received honoraria for speakers' bureau from Teva, Merck Serono, Biogen Idec, Bayer Schering, and Novartis. Nikhil Yawalkar received honoraria for speakers' bureau from Merck Serono, Biogen Idec and Bayer Schering.

Patient Preference and Adherence

\section{Publish your work in this journal}

Patient Preference and Adherence is an international, peer-reviewed, open access journal focusing on the growing importance of patient preference and adherence throughout the therapeutic continuum. Patient satisfaction, acceptability, quality of life, compliance, persistence and their role in developing new therapeutic modalities and compounds to

\section{References}

1. IFNB Multiple Sclerosis Study Group. Interferon beta-1b is effective in relapsing-remitting multiple sclerosis. I. Clinical results of a multicenter, randomized, double-blind, placebo-controlled trial. Neurology. 1993;43(4):655-661.

2. Jacobs LD, Cookfair DL, Rudick RA, et al. Intramuscular interferon beta-1a for disease progression in relapsing multiple sclerosis. Ann Neurol. 1996;39(3):285-294.

3. Johnson KP, Brooks BR, Cohen JA, et al. Copolymer 1 reduces relapse rate and improves disability in relapsing-remitting multiple sclerosis: results of a phase III multicenter, double-blind placebo-controlled trial. Neurology. 1995;45(7):1268-1276.

4. PRISMS Study Group. Randomised double-blind placebo-controlled study of interferon beta-1a in relapsing/remitting multiple sclerosis. Lancet. 1998;352(9139):1498-1504.

5. Steinberg SC, Faris RJ, Chang CF, Chan A, Tankersley MA. Impact of adherence to interferons in the treatment of multiple sclerosis: a non-experimental, retrospective, cohort study. Clin Drug Investig. 2010; 30(2):89-100.

6. Matson MA, Zimmerman TR Jr, Tuccillo D, Tang Y, Deykin A. Dose titration of intramuscular interferon beta-1a reduces the severity and incidence of flu-like symptoms during treatment intiation. Curr Med Res Opin. 2011;27(12):2271-2278.

7. O'Connor P, Filippi M, Arnason B, et al. $250 \mu \mathrm{g}$ or $500 \mu \mathrm{g}$ interferon beta- $1 \mathrm{~b}$ versus $20 \mathrm{mg}$ glatiramer acetate in relapsing-remitting multiple sclerosis: a prospective, randomised, multicentre study. Lancet Neurol. 2009;8(10):889-897.

8. Johnson KP, Knobler RL, Greenstein LI. Recombinant human beta interferon treatment of relapsing-remitting multiple sclerosis: pilot study results [abstract]. Neurology. 1990;40(Suppl 1):261.

9. Pachler C, Ikeoka D, Plank J, et al. Subcutaneous adipose tissue exerts proinflammatory cytokines after minimal trauma in humans. Am J Physiol Endocrinol Metab. 2007;293(3):E690-E696. optimize clinical outcomes for existing disease states are major areas of interest. This journal has been accepted for indexing on PubMed Central. The manuscript management system is completely online and includes a very quick and fair peer-review system. Visit http://www.dovepress.com/ testimonials.php to read real quotes from published authors. 